

\title{
The dynamic of crop-livestock systems in the Mediterranean and future prospective at local level: A comparative analysis for South and North Mediterranean systems
}

Véronique Alary, Charles-Henri Moulin, Jacques Lasseur, Adel Aboul-Naga, Mohamed Taher Srairi

\section{To cite this version:}

Véronique Alary, Charles-Henri Moulin, Jacques Lasseur, Adel Aboul-Naga, Mohamed Taher Srairi. The dynamic of crop-livestock systems in the Mediterranean and future prospective at local level: A comparative analysis for South and North Mediterranean systems. Livestock Science, 2019, 224, pp.40-49. 10.1016/j.livsci.2019.03.017 . hal-02620259

\section{HAL Id: hal-02620259 \\ https://hal.inrae.fr/hal-02620259}

Submitted on 22 Oct 2021

HAL is a multi-disciplinary open access archive for the deposit and dissemination of scientific research documents, whether they are published or not. The documents may come from teaching and research institutions in France or abroad, or from public or private research centers.
L'archive ouverte pluridisciplinaire HAL, est destinée au dépôt et à la diffusion de documents scientifiques de niveau recherche, publiés ou non, émanant des établissements d'enseignement et de recherche français ou étrangers, des laboratoires publics ou privés.

\section{(ㅇ)(1) $\$$}

Distributed under a Creative Commons Attribution - NonCommerciall 4.0 International 


\section{The dynamic of crop-livestock systems in the Mediterranean and future prospective at local level:}

\section{A comparative analysis for South and North Mediterranean systems}

\section{Abstract}

Mediterranean livestock farming systems have evolved to adapt to current and future pressures, including strong demographic growth and urbanization in the coastal zone, greater competition for land and water, and a big shift in the hinterland where farming activities are hardly maintained. We aim to explore future pathways for integrated crop-livestock systems in South and North Mediterranean countries to identify potential sustainable increases in efficiency and adaptability of resource utilization. The research was conducted in three countries, Egypt, France and Morocco, through case studies in a gradient of socioecological contexts, from favourable (plains and irrigated lands) to harsher ones (mountains, rain-fed areas). We mobilized farm surveys and monitoring, open-ended interviews, databases and previous studies. Based on a transversal analysis at the local level, we identified two main trends and five archetypical systems: (1) a centrifugal trend of specialization, towards cash crops or dairy herds in favourable areas, and pastoral system for meat production in harsher environments, and (2) a centripetal trend of diversification based on mixed crop-livestock systems in irrigation areas and agro-pastoral livestock-crop systems in intermediate rain-fed areas. The analysis showed an overwhelming antagonism between social vulnerability and ecological efficiency. Crop and livestock integration reduced the risk of biodiversity loss and low environmental efficiency observed in specialized systems, but mixed systems were more socially vulnerable. Those results call for dedicated rural development policies that favor the diversification as a lever of sustainable development but taking into account the land fragmentation and developing higher value added products chains. Taking advantage of spatial mobility abilities of livestock farming at the regional level, promoting collective actions must be encouraged to allow a wider range of livestock farmers in the hinterlands to live from their activities.

Keywords: adaptive capacity; development pathways; efficiency; livestock systems; Mediterranean 


\section{Introduction}

28

Over the last several decades, the Mediterranean agriculture systems have faced increasing pressures that include strong demographic growth, urbanization, increasing demand for animal products (especially in southern regions), a demand for safer animal products, and high competition for land and water. In this context, pressure on biomass to feed animals raises many challenges and sometimes competition in the trade-offs of the use of resources (land, water, and nutrients) that can affect the sustainable development of these systems (Dixon et al., 2010). Meanwhile, the synergies between cropping and livestock husbandry offer many opportunities for a sustainable increase in production, notably by raising productivity and improving resource use efficiency for both households and territories (Herrero, 2010). For example, Sraïri et al. (2011) showed that feeding system and agricultural practices improve water use efficiency in the crop-livestock systems in Morocco. Livestock activities are also recognized for their multiple roles in reducing vulnerability in fragile environments (Ashley, 1999; Alary et al., 2015; 2018) and their roles in diversification and intensification (Duteurtre and Faye, 2009). However, the main recent scientific assessments (IAASTD, 2009; IPCC, 2007) provide evidence of the difficulties of capturing the complex biological, social, and economic dynamics of the challenges likely to confront future crop and livestock production and their integration.

All over the world and especially in the Mediterranean basin, livestock farming systems have experienced important changes due to the extension of irrigation schemes and the social and political changes that have affected livestock management (settlement, mobility, and transhumance), land tenure and land use, and the sustainability of whole production systems. Although the South Mediterranean countries show an increasing demand for animal products that is linked to the demographic growth and emergence of a medium social class, North Mediterranean countries are experiencing a stagnating consumption of animal products of local origin (especially sheep meat). Over the last two decades, the 
North Mediterranean trends have been more driven by the public agricultural policies at the production level and, more recently, by the new environmental preoccupations embedded in the new supports (e.g., European agro-environmental measurements - AEM -).These trends endanger ecological equilibrium and socio-economic viability in these zones: the intensification in the South raises the question of the sustainable use of natural resources (soil and water), and the agricultural decline trend in the North threatens landscapes, biodiversity, and the social life in its hinterlands.

Finally, important cultural food changes linked to urban expansion and new life conditions are observed, as is increasing demand for "safe" and "ecological" or even organic products. These dynamics constitute new opportunities for agro-ecological systems in the Mediterranean zone, with potential pathways for livestock development. More generally, livestock has always played an important role in adding value to the resources in these environments, but high competition in animal products at the international level reduces profitability, while land access and comparative valorisation prospects at the regional level threaten the social and environmental sustainability of these systems and their future. This highlights future challenges concerning the efficiency of these systems and their contribution to food security.

In this direction, one of the key elements for developing a sustainable crop-livestock system is to promote intensification methods to produce more food using less land, water, and other resources (Matson et al., 1997). This concept that integrates ecological and economic efficiency was highlighted at Earth Summit 1992 by the World Business Council for Sustainable Development (WBCSD), as reviewed by Camarero et al. (2013). OECD (2000) has called eco-efficiency the efficiency with which ecological resources are used to meet human needs. It is approached by a ratio of an output (i.e., the value of products and services produced) divided by the input used (that measure the environmental pressures). This ratio can be assessed at different scales, from the firm to a sector, or even a local economy. From the end of the 2000s, the concept of ecological intensification focused more on sustainable processes in agriculture. Ecological intensification is achieved by considering the functioning and dynamic of ecosystems, the 
profitability and feasibility of technical options, and the social and technical viability of the new practices in liaison with the social and environmental system (CIRAD, 2010). This integrates the interactions between the actors, their activities, the environment and society. However, farm systems in the Mediterranean are diverse in their links with the socio-ecological environments. The Mediterranean livestock farming systems need therefore to adapt multiple and complex changes related to the recent history of the area and the predicted events in the near future (climate change, urbanization). This led us to pay special attention to the third pillar of sustainability, i.e., social sustainability, and address it, crossing ecological intensification with more integrative concepts: adaptive capacity and vulnerability. .

The overall objective of the paper is to increase the understanding of consistencies of croplivestock integration systems in three Mediterranean contexts (Egypt, France and Morocco) using databases and published data. The final goal is to help farmers, local communities, researchers and decision-markers in planning for Mediterranean livestock and designing priorities, rules, and policies that could better deal with the socio-environmental issues linked to demographic and land pressure, increasing demand and strong international competition.

\section{Methodology and materials}

Understanding the consistencies of crop-livestock integration systems in three Mediterranean contexts (Egypt, France and Morocco) necessitated gathering and integrating information regarding the socio-economic environment and the agronomic practices along with the available resources in each location. However, each country is diverse. As a first step, we identified geographical and social locations that reflect that diversity, from the agro-pastoral zones to the more intensified zones (Figure 1). This identification was based on the expert knowledge of the research teams in each country, supported by a review of the literature. This preliminary study allowed selecting different case studies in each country. In the south of France, the gradient expanded from the mountainous hinterlands of the region of Provence 
101

Alpes-Côte d'Azur (PACA) to the plains and Piedmonts of the coastal zones in the Languedoc and Roussillon regions that knew significant changes in links with the development of irrigation in the 1970s, the demographic pressures, the tourism development and the agricultural policies (Figure 1a). In Egypt, we selected a transect from the agro-pastoral systems of the North West Coastal zone to the New Reclaimed Lands (NRLs) in the western part of the Delta (Figure 2b). These NRLs are part of the national Egyptian strategy to increase agricultural production to enhance its food security. In Morocco, we opted for a long transect from the south side of Haut-Atlas (pastoral mobility) to the plain of Gharb (drip irrigation associated with maize silage and fodder production) (Figure 2c). Due to the characteristics of each country, the transects ranged from semi-arid or mountain systems in the less favourable zones to irrigation systems in the more favourable zones.

\section{[INSERT FIGURE 1]}

Data collection methods were based on several field and multiscale approaches, including the agrarian diagnosis at the territorial level (France, Morocco), bi-monthly or seasonal follow-ups at the livestock system level (Morocco, Egypt), and family farm surveys to identify livestock changes in the family's story and its environment (Egypt). We used qualitative and quantitative data collection systems based on semistructured questionnaires, guided interviews, or open discussions in participatory approaches (Table 1).

[Insert Table 1]

The analysis of the systems aimed at producing and integrating the technical, economic, and environmental parameters to assess the economic and environmental efficiency of integrated crop-livestock system along the defined geographical transect of intensification. This assessment has mobilized different methods and tools. For Morocco and Egypt, a series of indicators related to family (labour constraints, per capita 

al., 2017).

income), feed system (feed availability, feed autonomy), crop-livestock interaction ( $\mathrm{N}$ management) and animal performances (milk production, animal transactions, expenses related to animal production) have been estimated based on declarative farm surveys. They resulted from the annual follow-up of 14 farmers in the plain of Gharb (Morocco) and a farm survey (175 farms) in West Delta (Egypt). In France, we used previous studies of sheep farms in the Mediterranean area (Bataille et al., 2016) to assess the services provided at the territorial level by a combination of specialized of mixed crop-livestock types (Lurette et

The evaluation of eco-efficiency has been crossed with the concepts of adaptive capacity based on the trajectory of change (McAllister et al., 2006; Ploeg, 1994) and the concept of vulnerability based on the livelihood framework (Ellis, 2000). In the approach of adaptive capacity of a system by McAllister et al. (2006), the questions of the future of the systems are based more on their ability to co-evolve the different components of the system than to control the dynamics of each component. Ploeg (1994) underscores the importance of assessing the livestock activities in their capacities to change with the local perceptions and expectations of the population on these activities. This approach favours an analysis of the collective capacities to contribute to a project that itself evolves dynamically, i.e., the collective capacity for innovation and diversity of systems and contribution of socio-technical networks (Darre, 1999; Ploeg, 2004; Renting and Ploeg, 2011). However, we suppose that this capacity is combined with the tangible and intangible assets of each individual in the collective that will influence its capacity to act collectively. For that, we used Ellis' (2000) livelihood framework. Based on these hypotheses and a literature review, we have selected eight major drivers of a farming system's strengths or weaknesses that may impact the pathways towards sustainability (presented in Table 2). 

trends of specialization-diversification towards crop or livestock activities. Then, from the various previous results at farm or territorial levels, we synthetized the strengths and weaknesses of those farming systems towards sustainability.

\section{Results}

\subsection{From complex realities towards a typology of farming systems}

158

To understand the whole system, we elaborated a typology of the modalities of crop-livestock integration in each case study. Six farm types have been identified and described in the New Reclaimed Lands of West Delta (Egypt) according to a gradient of specialization or diversification and a gradient of capital assets (mainly based on land access) (Alary et al., 2016a). This classification identified two main trends of specialization or diversification according to the educational level of the family's head. On the one hand, we identify the groups of 'graduated' farmers; these two groups have accessed to five feddans (around 2 ha as 1 feddan $=0.42$ ha) of land according to the Moubarak settlement scheme set up in the 1980s, and they followed a specialization path towards establishing tree plantation. In the other hand, the groups of traditional farmers have maintained, integrated and diversified crop-livestock systems, as compared to the old lands of the Nile Valley and Delta. In the traditional groups, we can identify different groups according to cultivated land size, from the smallest ones with only one ha land and one to two dairy animals to largest ones with around 5 to 10 ha and 15 to 20 dairy animals in the sample.

In the French Mediterranean region, livestock is a specialized activity at the farm and territorial scale. In the mountainous region of PACA, we estimated that only $6 \%$ of the farmland of livestock farms 
were not directly dedicated to forage cropping or grazing, and two-thirds of these are cereal crops, among which a large part is devoted to livestock feeding. This specialization is illustrated by an agrarian diagnostic at the local level based on open-ended interviews and mapping analysis of agricultural census data (Prud'hon, 2016). Raising livestock, especially sheep farming, is the main activity in the hinterlands, taking advantages of summer pasture availability and relying of a mix of forage and cereal crops in the upper valley for sheep and cattle farming. This specialization of wide areas is historically based on exclusions promoted by the opportunity for extensions of high-value productions (vineyards, orchards in lowlands). Extension of irrigation infrastructure on a large scale (cereals and orchards in large valleys), chemical farming that reduces interest for crop-livestock integration over the last 50 years, and specific financial support for livestock in mountain areas have reinforced this. However, this spatial trend of spatial dissociation for farming activities is actually being questioned, and we can notice some inflexions. We can observe new agreements between specialized livestock farmers and crop farmers for extending organic farming, agreements sometimes favoured by new incentives of European policies. This led to new opportunities to reintroduce livestock in specialized cropping systems thanks to regional livestock mobility.

In the Gharb Plain (Morocco), based on different weights of livestock in the farming systems, and considering particularly income generation, land occupation and work time mobilization, we identified three types of farms: the livestock-oriented farms towards dairy production, the market horticulturaloriented farms, and the traditional mixed crop-livestock farms.

The specific approach of the farming systems and the various roles of livestock in each location reveal contrasting situations between North and South Mediterranean countries regarding the angle of approach (farm to regional approach) and between case studies regarding the indicators of differentiation. While specialization processes are dominant in France, we observe two different factors of differentiation of mixed crop-livestock systems in the south countries. Land access and land availability are the more 
constraining factors in Egypt that affects the livestock dynamics and the farming systems, although labour productivity becomes a critical trending factor of the systems in Morocco.

\subsection{Efficiency and sustainability evaluation at the farm and territorial level}

As mentioned in the methods section, the eco-efficiency assessment analysis of the systems has been based on technical, economic, and environmental parameters calculated in each case study. Even if the indicators are not identical for the three case studies, they allowed characterizing the global efficiency and outcome of crop-livestock integration for each case study.

In Morocco, the results show clearly the weight of the feed availability constraints, especially in the dry season, with a hard daily routine for dairy activities (Table 3). Due to constraints related to feed availability, the feed costs reach around $66 \%$ and $75 \%$ of the milk price, respectively, in rainy and dry seasons. The hard daily routine in the livestock systems is not compensated by high yield or market price; this explains low labour productivity (two times less than in crop and crop-livestock systems). However, in this approach, we neglect the non-economic roles like organic fertilization and the role of livestock in terms of diversification and risk management (Sraïri et al., 2014; Sraïri and Ghabiyel, 2017).

[Insert tables 3]

In Egypt, a set of technical economic and environmental parameters has been estimated for the six farm types (Table 4). The table shows clearly, for all farm types, the significant contribution of organic manure in nitrogen management, representing around $46 \%$ of the total nitrogen input in 2013/14. However, this organic matter aims mainly to constitute the soil subtract in these desert lands for cultivation. As soon as the soil became productive, we observed a reduction or abandonment of livestock in the farm systems, especially in the tree specialized systems (G5 and G6). This category continued to 
enrich the soil with poultry droppings purchased from semi-intensive poultry farms. This tree specialization served as a model for traditional farms that converted progressively part of their land to plantations in 2014 as a strategy of market diversification. The biomass constitution and preservation are key-factors of the sustainability of this system in desert environments. Contrariwise, the economic parameters revealed a contrasting profile of roles of livestock according to the farm specialization or degree of diversification. Firstly, the large mixed system oriented to dairy (G4) generated the highest economic outcome per family workforce or per land unit, followed by the tree specialization system. These tree systems were not yet stable in the zone due to recent planting, which explained the limited fruit yield for new planters. However, these economic indicators reveal the social and economic vulnerability of integrated small-scale systems compared to specialized ones.

[Insert Table 4]

In France, analyses of agrarian dynamics at the local level showed that the productivity of labour and land were also two major drivers explaining the specialization of the farms towards crops or towards livestock (Thomas, 2014; Aubron et al., 2016). The main stake concerned environmental issues about the use of rangelands and maintenance of open landscapes in the hinterlands. We analysed the services provided by the farms in an area of the Préalpes, combining crop or livestock specialized farms and mixed farms. We modelled scenarios with a complete specialization of farms (abandonment of livestock in mixed farms) or diversification (livestock activities in crop-specialized farms). We showed (Lurette et al., 2017) that the current situation maximized the number of farms in the territory. On the one hand, crop specialization decreased the total number of workers $(-18 \%)$, with a slight increase of the income per worker $(+3 \%)$, and led to an abandonment of $50 \%$ of the rangelands used in the current situation. On the other hand, the diversification with livestock enabled maintaining the amount of cereal production, increased meat production $(+24 \%)$ and use of rangelands $(+44 \%)$. The current trade-offs enabled 
maximizing the number of farms and workers with a good level of the average income per worker (rural vitality), but at the expense of the use of rangelands (environmental issues). This analysis showed the interest in a diversity of farms in a territory, but also the difficulty to maximize all the services in a bundle (Dumont et al., 2017).

\subsection{Assessment of the adaptive capacity to changes based on social arrangements}

Despite this trend of apparent dissociation of crop and livestock activities at the farm level, especially for cash crops and dairy specialized systems, a dynamic of relationships between specialized farms and mixed crop-livestock farms can be identified at various spatial scales in the three countries. Specialized crop farms provide opportunities to access to feed resources (mainly crop by-products, such as cereal straw, bran, stubble and weeds from fruit tree plots) for livestock farms, and the livestock farms provide opportunities to valorise biomass and products available on crop farms. The mobility of herds is a key factor to reconnecting crops and livestock. This analysis was mainly developed in the less favourable zones in each case study.

For example, in France, sheep farming in the Mediterranean areas previously relied on forage resources combined from contrasted components of the landscape (Sylva, Saltus and Ager), and mixed farming was the pivot. We identified new trends in crop-livestock integration mostly based on relationships between farmers, sometimes spatially distant. Crop and livestock integration is now at stake at the territory level to increase feed autonomy, efficiency in resource consumption and adaptation to global change. Collective action is an effective tool to reinforce integration. This research relied on comprehensive interviews with stakeholders to identify socio-technical networks, involvement of livestock farmers in crop-livestock integration initiatives, and consequences on livestock farms and practices. A multitude of actors involved in these initiatives (local policy-makers, environmental and/or inhabitant associations, landowners) had to gather with livestock and crop farmers, thus underscoring the importance 
of negotiations. From these collective interviews, we identified three ways to foster crop-livestock integration at the territorial level: $i$ ) vicinity grazing on cash crop fields based on traditional neighbourhood relationship; ii) distant winter grazing based on bilateral agreements between livestock farmers and vineyard growers; and iii) distant forage cropping on vineyard wasteland in suburban plains (Mohamed M., 2015).

The cross analysis of these spatial organizations with the social arrangements allowed defining the different roles of social, spatial and temporal coordination in the systems' adaptive process along an agroecological gradient of integration (Table 5).

[Insert table 5]

In the Haut-Atlas (Morocco), the analysis of the territorial system based on the characterization of the transhumance systems and the interactions of the different systems (pastoral, agro-pastoral, oasis systems) linked with the spatial and social organization reveals the specific roles formerly defined by the users in territorial resource management. The results show clearly that the viability of the pastoral system has reached its limits due to ecological constraints. Farmers have become obliged to leave their territory during winter because of lack of resources due to pastoral pressure. This individual regulation is possible for medium and large flocks, but difficult for small herders. Moreover, this alternative is fragile and starts to provoke social conflicts with neighbouring territories. In this context, collective regulation of pastureland access appears to be a condition to maintain the social territorial unity (mainly between small and large flocks) and ecological resources. This requires new forms of regulation, known as co-viability, that are legitimized at the local level (Barrière, 2008).

Extensive studies in the rain-fed area of the west part of the Delta (Egypt) confirmed the importance of flock mobility for large and medium-size farms to adapt to resource constraints. Interviews with the Bedouin breeders around the settlement zone of Tiba allowed drawing of the herd mobility paths 
in the zone and estimating the nitrogen supply based on the herd size and the duration of grazing. This contribution ranged from $6 \%$ to $25 \%$, depending on the village or grazing zone in $2014 / 2015$. This can explain the lower $\mathrm{N}$ intake (chemical and organic) used by crops in this zone (especially for G5).

These three case studies show common factors of adaptability of livestock farms based on the territorial exploration of resources through mobility. However, this adaptive capacity concerned mainly large and medium-size farms that have the social capital to manage mobility for their flocks and extend flock size and, as a result, increase labour productivity. Mobility clearly is a strong attribute of Mediterranean systems regarding adaptation (see Ocak, 2016).

A strong discrimination may be operated between, $(i)$ on the one hand, livestock farmers who may base the future of their farms on this option related with special assets (social capital and networks due to historical background of the families or tribes) that enable them to move as well as public policies incentives; and (ii) on the other hand, livestock farmers who may not foster mobility but on local enrolment, activating diversification (tree plantation, vegetable, agro tourism) or plural activities while they do not benefit in mobility assets and initiate another scope for their activity. At the regional level, it appears that to avoid exclusion and maintain availability of contrasted pathways that guarantee diversity, regulations must be implemented that will reinforce the collective resilience.

\section{Attempt of prospective for future livestock systems in Mediterranean}

From the three country case studies, we can identify five common farming systems (FS) pathways in these Mediterranean contexts. First, we observe three trends of specialization of farming systems due mainly to policy incentives and infrastructure development. The first trend concerns the development of high-value cash crop-specialized systems in the favourable zones, mainly irrigation zones. This specialization is largely driven by labour productivity and social valorisation linked with the educational level or aspirations in terms of living conditions. This trend extends in all the plains of the coastal line in 
the south of France and Morocco and in the recent NRL in Egypt. It has also been encouraged by regional and national policies of rural development in France and in Morocco based on irrigation development and agrarian reform in Egypt in favour of graduates and private entrepreneurs. The second trend is dairy specialized system which is developing in the favourable zones of Morocco and Egypt. This specialization concerns mainly large dairy farms and some smallholder farms that have been boosted, and sometimes structured, by the milk agro-industrial sector through a secured farm gate milk price and regular sales of calves. The third and last trend is related to meat specialized systems in vulnerable zones like the mountainous areas in France or the arid and semi-arid zones in Morocco or Egypt. This specialization depends on the capacity to increase resource access by mobility, thanks to an extended social network.

In this common trend of specialization, we can easily differentiate the 'modern' or 'capitalist' specialization towards the high-value crops or dairy products driven by the national or multinational firms (the so-called modern sector), from the specialization towards meat production in the vulnerable zones mainly driven by individual capital assets.

Furthermore, we can identify two trends of maintenance of the diversification. This concerns two types of farms: (i) The mixed crop-livestock systems in which crop activities are the main source of income and (ii) The mixed livestock-crop systems in which livestock is the main source of income. If the first type constitutes the majority of farming systems in the NRL and in the irrigated zones of Morocco, it is no longer present in the south of France, limited in the interstice between the plains and the mountains. The second type oriented to livestock represents the majority of integrated systems in the rain-fed zone, also called agro-pastoral system due to the maintenance of short seasonal mobility during the favourable climatic years.

From these different development pathways, we can represent the dynamic of farming systems in the area by two main trends: a centrifugal trend of specialization that is the strongest in France and a centripetal trend of diversification that is most widespread in Egypt and Morocco (Figure 2). 
Table 6 gives a brief overview of the weight of the types of farming systems in the studied zones. This table highlights the main differences of trends between South and North Mediterranean contexts, but it shows also the more recent developments of crop or livestock specialized systems in the South Mediterranean, driven by agricultural policies oriented to intensification and modernization, and the agroindustrial development over the last two decades. The two studied zones in the south are emblematic of this trend through the Green Morocco Plan (Plan Maroc Vert -PMV-) in Morocco and the settlement program in the New Reclaimed lands of Egypt, with the installation and specialization of medium-size farms.

[Insert table 6]

The comparison of eco-efficiency in the three-country case study was based on three main synthetic indicators: 1) nitrogen use efficiency for environmental assessment, 2) the economic vulnerability based on the diversification of income sources, and 3) the labour productivity that reflects the technical and economic performances (Table 7). If the farming system with a livestock component is more environmentally efficient due to the organic matter supply, the main difference of the systems is between economic vulnerability and labour productivity. If the mixed systems are more resilient to economic or market shocks, they are less attractive in terms of yearly gains. The mixed or specialized livestock systems in the rain-fed areas are the most dependent on climatic events that can affect the economic vulnerability of mixed farming systems and labour productivity of specialized farming systems. 
[Insert Table 7]

Using the two frameworks for adaptive capacity and vulnerability, we have identified the five farming systems according to eight major drivers of strengths or weaknesses in terms of sustainability. Table 8 shows the different strengths between irrigated and non-irrigated systems: if the irrigated systems have been supported by national territorial development policies that include road infrastructure, the livestock specialized systems in the rain-fed zone resulted from social coordination. In between, without social coordination actions or policy support, the mixed systems - the environmentally friendly systemsare the most vulnerable. This approach showed the high correlations of strengths and weaknesses for all the farming systems between policy support, land and resource access and market access. This supports the idea of the decisive influence of the policy development on the present specialization of the systems based on land assets.

[Insert Table 8]

\section{Discussion}

Our main hypothesis of this transversal research work was that the integration of crop-livestock activities, at the farm or regional level, is a pillar of sustainability of the farming system mainly in terms of environmental efficiency. However, in the South Mediterranean, the integrated crop-livestock systems remain the only option for small-scale farms in rain-fed and irrigated zones due to limited assets, either land or market access, and given their overwhelming number of workers. The weak access to market constitutes a major handicap for new settlers in the recently reclaimed lands of Egypt located more than $100 \mathrm{~km}$ from large cities such as Cairo and Alexandria. The integrated crop-livestock systems, however, still ensure the survival of many families and workers, particularly in contexts of significant risks, like prices volatility and climate hazards. In fact, in the South Mediterranean context, where irrigation water 
may not be sufficient to cover all crop needs, in case of acute drought, livestock remains the only source of income to cover farmers' expenses and the main security in case of major social events (like marriages, funerals, hospitalizations). In addition, livestock in many situations adds value to rainfall, with almost no effect on groundwater depletion (Sraïri et al., 2016), in contrast many summer crops that have a huge effect on the sustainability of ground water resources (Ameur et al., 2017).

In the three countries, the compared labour productivity of crop and livestock activities explained the specialization trends towards cash crops such as vineyards, tree plantations, and market gardening in favourable areas like irrigation plains. Over the last two decades, this farm specialization has led to a territorial specialization in France: livestock disappeared in coastal plains and valleys, and cash crops were no longer present in the hinterlands. In Egypt and Morocco, mixed systems still exist in irrigation areas, in combination with specialized crop farms. In those mixed systems, labour is a key factor in terms of quantity, routine tasks and remuneration. At the family level, the diversion of youth from agricultural activities, given its limited attractiveness due its limited revenues, can be a threat to viability; however, it is not a recent phenomenon in Morocco (Bencherifa, 1993; Lubbock and Borquia, 1998). Furthermore, recently, we may find new arrangements, notably the remuneration of family work or new social arrangements such as farm associations and work sharing between farms to keep interest in agriculture (Bencherifa, 1993). However, this may weaken the whole system in the long term, whenever the equilibrium between social demands and the existing resources might collapse due to the end of state technical support for farmers and the emergence of new needs such as better education services for the children (Sraïri, 2005). In Egypt, we observed the highest profits of livestock activity for medium-size and large farms while small mixed crop-livestock systems registered the higher return by capital invested in livestock. This reflects the multiple roles of livestock in farm assets.

In the mixed farm systems, as in Egypt and Morocco, or in specialized livestock farms relying partially on fodder and grains provided by cropland in France, the crops provided most of the feed resources to herds or supply resources to get through harsh seasons. The results obtained in the three 
countries stressed also the crucial function of livestock biomass preservation in the Mediterranean context, through the role of manure to improve the stock of organic matter of the soil. Using manure was a way to maintain soil fertility and reduce the use of mineral fertilizers. Thus, the crop-livestock integration, through feeding and manure management, decreases external inputs. Nevertheless, the practices of croplivestock integration, especially manure management, created a heavy workload. Even in farms managing both crops and livestock, those activities could be not integrated, or in a one-way path only, with any recycling.

Previous research showed that increased demographic pressure and cropping intensity favoured the degree of integration of crop-livestock activities (Boserup, 1965; Ruthenberg, 1980; Pingali et al., 1987). This process was fostered with market access, diffusion of technology packages, or the presence of cash crops in the cropping pattern (McIntire et al., 1992). This process is still on-going in the south Mediterranean countries. However, our results show that these systems, while ecologically most efficient, are also socially deeply vulnerable. They are maintained in Morocco and Egypt "by default" and as protection from uncertainties and risks, supported by social solidarities that substitute for lack of dedicated policies. This antagonism between social vulnerability and ecological efficiency should be a major consideration for rural development policies in the south to avoid the disappearance of such systems that we may notice in many areas in northern Mediterranean countries.

Consequently, for the future, limiting micro-regional specialization processes through by maintaining a diversity of systems, both crop-oriented and livestock-oriented, is at stake. This relies on special supports to reduce competition between these systems, reinforcing the ability of livestock systems to be perennial and reducing the common trends observed of substitution of livestock systems (mainly oriented for meat production) by enlargement of crop oriented systems. This requires dedicated actions confronting local feeding systems. This could rely on special incentives and development of territorial food projects. Special environmental rules would reintroduce diversity in cropland occupation such as reintroducing legumes in cultural successions is another way to foster a mix within farming systems. While 
we may notice that specialization at a micro-regional level results in loss of environmental efficiency for areas devoted to crop systems, taking advantage of the spatial mobility abilities of livestock farming in the Mediterranean is an another option to reinforce crop-livestock integration at the regional level. This mobility has been traditionally operated by medium to large-size farmers (Lasseur et al, 2016). However, promoting collective actions allowing a wider range of livestock farmers in the hinterlands to participate should reinforce sustainability for vulnerable livestock farmers and those with limited animal wealthwhile extending cropping areas. These collective actions should involve a wide array of stakeholders.

Nowadays, the adaptive capacity in the Mediterranean area is strongly based on regional integration and diversification. These processes involve different configurations at the time and spatial levels according to the agro-ecological gradient (from rain-fed to irrigated zone) but also the regional policy of territory development.

This research has also developed a series of indicators to approach the efficiency of crop/livestock systems according to a gradient of intensification and using tools ranging from livelihood and microeconomic tools (for economic and social assessment) to environmental tools like network analysis. Beyond these data sources and tools, the transversal analysis highlights that livestock at the interface between land management (local) and livelihood diversification (family) plays a vital role in the current rural sustainability, although its future will depend on the societal challenges and policy orientation between employment, food security and resources management. Moreover, the function of livestock in biomass management appears crucial for the medium- and long- term resilience of Mediterranean agrarian systems.

\section{Conclusion}

For small ruminant systems (sheep and goat) that are dominant in the rain-fed and mountainous areas of the Mediterranean, we observed an increasing flexibility of medium and large flock systems based on spatial and temporal mobility. This geographical and social expansion went hand in hand with a certain 
level of specialization. The permanence of small flock systems in the South Mediterranean countries was observed, where the pillar of viability depended on the diversification of farm outputs. In the irrigation areas, we found more contrasted situations between the locations according to the social and political environment. The irrigated systems in the Mediterranean zones tended to specialize in high remunerative crops like orchards or market gardening in the south of France or plain of Gharb in Morocco or specialized fruit production in the West Delta of Egypt. Only farms with small-irrigation land area (which constituted the majority in the South countries) maintained a crop-livestock diversification to secure not only their source of income, but also their family's food supply and savings.

Facing this trend of specialization with detected environmental (and economic) risks and the maintenance of a mass of small mixed crop-livestock systems (not necessarily viable, notably in terms of transmissibility and reproducibility), collective regulations appear as a key-driven solution, and incentives to increase resilience of the whole system should rely on maintaining contrasted pathways for farms and diversity management.

This study shows that different pathways of development can be proposed according to policy priorities or farmers' expectations. In the rain-fed areas, the results highlight that the local (territorial) perception of development is often far removed from the spatial dynamics of livestock that generally favour a diversity of livelihoods at the landscape level. In this context, mobility driven by agro-ecological conditions and stakeholders' networks constitutes a powerful adaptive strategy in the face of climate change. Nevertheless, these networks have also favoured agricultural development (mainly through irrigation in PACA or Wadi development with orchards in rain-fed Egypt). Consequently, a new integrated livestock-crop model based on local fodder and concentrates is needed. This shows the capacity of livestock activities to reach new agricultural areas adapting to land pressure, but also to respond to emerging food demand with new lifestyles. The permanence, yet adaptability, of livestock confirm its role as a security net in this type of harsh environment. In the irrigated areas, particularly in large scale irrigation schemes, we observe the development of dairy or crop-specialized systems, encouraged by 
regional and national policies of rural development, but with a loss of environmental efficiency. This model could be improved by taking advantage of the spatial mobility abilities of livestock farming in the

500 Mediterranean to reinforce crop/livestock integration at the regional level. This will certainly also improve 501 the value addition to several resources like rainfall and surface irrigation water (small dams, springs) at a time when severe regulation should be devoted to groundwater resources to avoid amplifying rural exodus. 
505 The material presented here has been collected in the framework of a collaborative research project 506 CLIMED on "The future of Mediterranean Livestock Farming Systems: opportunity and efficiency of 507 Crop-Livestock Integration". This project associated CIRAD (Centre International de Recherche 508 Agronomique pour le Developpement), INRA (Institut National de la Recherche Agronomique), Supagro, 509 ICARDA (International Centre for Agricultural Research in the Dry Areas), Animal Production Research 510 Institute, Egypt (APRI) and Hassan II Agronomy and Veterinary Medicine Institute (IAV Hassan II), 511 Morocco . We especially thank all the researchers from the sheep and goat research department APRI for 512 their active participation, the students in France and Morocco and all the farmers and stakeholders in the 513 studied areas for the time that they spent with us. This work was supported by the French national research 514 agency (ANR) and the Ministry of Higher Education in Morocco (ARIMNET program)). 
Adger, W.N., Vincent, K., 2005. Uncertainty in adaptive capacity. Geosciences. 337(4), 399-410

Alary, V., Aboul-Naga, A., El Shafie, M., Abdelkrim, N., Hamdon, H., Metawi, H., 2015. Roles of small

Alary, V., Corniaux, C., Aboulnaga, A., Galal, S. (Eds), 2016a. Atlas of the traditional milk sector around

Greater Cairo in Egypt. CIRAD, APRI, ICARDA, Cairo University \& Ain Shams University. 82 p. https://umr-selmet.cirad.fr/actualites/l-atlas-du-projet-dairy

529

Alary, V., Messad, S., Daoud, I., Aboul-Naga, A., Osman, M.A., Bonnet, P., Tourrand, J.-F., $2016 b$.

Social Network and Vulnerability: A Clear Link in Bedouin Society (Egypt). Human Ecology. 44, 81-90

Ameur, F., Kuper, M., Lejars, C., Dugué, P., 2017. Prosper, survive or exit: Contrasted fortunes of 207-217.

Ashley, S., Holden, S., Bazeley, P., 1999. Livestock in Poverty-Focused Development. 
541 Aubron, C., Noel, L., Lasseur, J., 2016. Labor as a driver of changes in herd feeding patterns: Evidence 542 from a diachronic approach in Mediterranean France and lessons for agroecology. Ecological Economics.

$543127,68-79$.

544

545 Barrière, O., 2008. Legal aspects of the co-viability of social and ecological systems in African arid zones: an anthropological approach to environmental law. In: Lee, C., Schaaf, T. (Eds), The future of

547 drylands. Springer-Verlag\&Unesco publishing, Paris, 583-597.

548

549

Bataille, J.F., Sauguet, F., Mary, J.P., Lagier, E., Leconte, R., Marty, G., Poucheret, P., Pagès, L., Balme,

550 J.L., 2016. Approche de la diversité des systèmes ovins viande à composante pastorale localisés dans le

Bencherifa, A., 1993. Migration Extérieure et Développement Agricole au Maroc. Etat de la connaissance, Observations Empiriques Récentes, et Perspectives de Recherches Futures. Revue de

Berkes, F., 2007. Understanding uncertainty and reducing vulnerability: lessons from resilience thinking.

Nat Hazards. 41, 283-295. 
Blondel, J., 2006. The design of Mediterranean landscape: a millennial story of human and ecological systems during the historic period. Human Ecology. 34, 713-729.

Boserup, E., 1965. The Conditions of Agricultural Growth: The Economics of Agrarian Change under Population Pressure. London, G. Allen and Unwin, Chicago: Aldine, 124 p.

Brooks, N., 2006. Climate change, drought and pastoralism in the Sahel. Discussion note for the World Initiative on Sustainable Pastoralism.International Union for Conservation of Nature, Gland, Switzerland. https://cmsdata.iucn.org/downloads/e_conference_discussion_note_for_the_world_initiative_on_sustaina ble_pastoralism_.pdf (accessed 18 June 2018) OECD Countries. Environmental and resource Economics. 55(1), 87-106.

Cecchi, C., Wint, W., Shaw, A., Marietta, A., Mattioli, R., Robinson, T.P., 2010. Geographic Distribution and Environmental Characterization of Livestock Production Systems in Eastern Africa. Agriculture, Ecosystems and Environment. 135, 98-110. 
Darré, J.P., 1999. La production de connaissances pour l'action. Argument contre le racisme de

l'intelligence. Co-Edition Maison des sciences de l'homme, INRA, Paris, 242p.

590

Dixon, J., Li, X., Msangi, S., Amede, T., Bossio, D., Ceballos, H., Ospina, B., Howeler, R., Reddy,

B.V.S., Abaidoo, R., Timsina, J., Crissman, C., Mares, V., Quiroz, R., Leon-Velarde, C., Herrero, M.,

Blummel, M., Holmann, F., Peters, M., White, D., Qadir, M., Szonyi, J., 2010. Feed, food and fuel:

594

595

596

597

598

599

600

601

602

603

604

605

606

607

608

609

610

611

612
Competition and potential impacts in small crop-livestock-energy farming systems, CGIAR Systemwide Livestock Programme, project report. SLP, Addis Ababa, Ethiopia, 114p.

Dougill, A. J., Fraser, E. D. G., Reed, M. S., 2010. Anticipating vulnerability to climate change in dryland pastoral systems: using dynamic systems models for the Kalahari. Ecology and Society. 15(2), 17.

Dumont, B., Ryschawy, J., Duru, M., Benoit, M., Delaby, L., Dourmad, J.-Y., Méda, B., Vollet, D., Sabatier, R., 2017. Les bouquets de services, un concept clé pour raisonner l'avenir des territoires d'élevage. INRA Productions Animales. 30 (4), 407-422.

Duteurtre, G., Faye, B., 2009. L'élevage, richesse des pauvres : Stratégies d'éleveurs et organisations sociales face aux risques dans les pays du Sud. Editions Quae, Versailles, France, 286p

Eakin, H., 2005. Institutional change, climate risk, and rural vulnerability: cases from central Mexico. World Development. 33(11), 1923-1938.

Ellis F. (2000) Rural livelihoods and diversity in developing countries. Oxford University Press, New York. 
613

614

615

616

617

618

619

620

621

622

623

624

625

626

627

628

629

630

631

632

633

634

635

636

Ellis, F., Mdoe, N., 2003. Livelihoods and Rural poverty reduction in Tanzania. World Development. 31(8), 1367-1384.

Folke, C., Hahn, T., Olsson, P., Norberg, J., 2005. Adaptive governance of social-ecological systems. Annu. Rev. Environ. Resour. 30, 441-73.

Fraser, E.D.G., Stringer, L.C., 2009. Explaining agricultural collapse: Macro-forces, micro-crises and the emergence of land use vulnerability in southern Romania. Glob. Env. Change. 19, 45-53

Herrero, M., Thornton, P.K, Notenbaert, A.M., Wood, S., Msangi, S., Freeman, H.A., Bossio, D., Dixon, J., Peters, M., van de Steeg, J., Lynam, J., Parthasarathy Rao, P., Macmillan, S., Gerard B., McDermott, J. Seré, C., Rosegrant, M., 2010. Smart investments in sustainable food production: Revisiting mixed crop-livestock systems. Science. 327(5967), 822-825.

Lubbock, A., Borquia, R., 1998. Survival, Change and Decision-Making in Rural Households: Three $\begin{array}{lllll}\text { Village } & \text { Case } & \text { Studies } & \text { from } & \text { Eastern }\end{array}$ https://scholar.google.com/scholar?hl=en\&q=Bourgia\%2C+R.+\%281998\%29\%2C+Survival\%2C+Chang e+and+Decision\%E2\%80\%90Making+in+Rural+Households\%3A+Three+Village+Case+Studies+from+ Eastern+Morocco\%2C+IFAD\%2C+Denmark (accessed 18 June 2018).

IPCC (Intergovernmental Panel on Climate Change), 2007. Climate Change 2007: Impacts, Adaptation and Vulnerability. Summary for Policy makers (Island, Washington, DC, 2007), 73p. www.ipcc.ch/publications_and_data/ar4/syr/en/contents.html (accessed 18 June 2018). 
637

638

639

640

641

642

643

644

645

646

647

648

649

650

651

652

653

654

655

656

657

658

659

660

IAASTD (International Assessment of Agricultural Science and Technology for Development), 2009). Agriculture at the crossroads: Global Report. Island, Washington, DC, 590p.

Lasseur, J., Alary, V., Aboul-Naga, A., Osman, M.A., Salah, E., Daoud, I., Bonnet, P., 2016. Adaptability of small ruminant farmers facing global change. A North-South Mediterranean analysis. In Thiébault, S., Moatti J.P. (Eds.), The Mediterranean region under climate change: a scientific update. IRD, AllEnvi, France, 477-484.

Lavorel, S., 1999. Ecological diversity and resilience of Mediterranean vegetation to disturbance. Diversity and distribution. 5, 3-13.

Lurette, A., Lecomte, L., Bataille, F., Lasseur, J., Moulin, C.H., 2017. Les impacts de l'intégration agriculture-élevage sur les services rendus par l'agriculture en territoires méditerranéens: approche par scénarios. https://colloque.inra.fr/polyculture-elevage2017/Presentations (accessed 19 June 2018).

Matson, P.A., Parton, W.J., Power, A.G., and Swift, M.J., 1997. Agricultural Intensification and Ecosystem Properties. Science. 277(5325), 504-509.

McAllister, R.R.J., Abel, N., Stokes, C.J., Gordon, L. J., 2006. Australian pastoralists in time and space: the evolution of a complex adaptive system. Ecology and society. 11 (2), 41

McIntire, J., Bourzat, D., Prabhu, P., 1992. Crop-livestock interaction in sub-Saharan Africa. https://vtechworks.lib.vt.edu/handle/10919/65734 (accessed 18 June 2018) 
661

662

663

664

665

666

667

668

669

670

671

672

673

674

675

676

677

678

679

680

681

682

683

684

Mohamed M., 2015. L'intégration agriculture-élevage entre exploitations spécialisées pour alimenter les troupeaux méditerranéens ovins en France. Mémoire de fin d'étude d'ingénieur ISTOM. 83 p+annexes

Ocak, S., 2016. Transhumance in Central Anatolia: A resilient interdependence between biological and cultural diversity. J Agric Environ Ethics. 29, 439-453.

OECD, 2000, Towards Sustainable Development - Indicators to measure progress, Paris. http://www.oecd.org/site/worldforum/33703694.pdf

Olsson, P., Folke, C., Hahn, T., 2004. Social-ecological transformation for ecosystem management: the development of adaptive co-management of a wetland landscape in southern Sweden. Ecology and Society. 9(4), 2 .

Pingali, P.L., Bigot, V., Binswanger, H., 1987. Agricultural Mechanization and the Evolution of Farming Systems in sub-Saharan Africa. Johns Hopkins University Press, Baltimore, MD.

Ploeg (van der), J.D., 1994. Styles of Farming: An Introductory Note on the Concepts and Methodology. invan der Ploeg, J.D., Long, A. (Eds.). Practice and perspectives of endogenous rural development. Van Gorcum, Assen, p. 7 - 31. http://library.wur.nl/WebQuery/wurpubs/28143 (accessed 18 June 2018)

Ploeg (van der) J.D., 2004. Mobilizing local actors: Stakeholder activities and networking in rural areas. http://library.wur.nl/WebQuery/wurpubs/personal/337319?wq_inf1=p1014633 (accessed 18 June 2018)

Prud'hon T., 2016. L'élevage herbivore en région PACA Analyse et mise en place d'une base de donnée. Master 1 Espaces Ruraux et Développement Local Année 2015/2016. Université Paul-Valery Montpellier 
Renting, H., Ploeg (van der), J.D., 2011. Reconnecting nature, farming and society: environmental cooperatives in the Netherlands as institutional arrangements for creating coherence. Journal of

693

Ridaura, S.L., 2005. Multi-scale sustainability evaluation- A framework for the derivation and 695 quantification of indicators for natural resource management systems. Tropical Resource management papers, 68, 202p.

697

Ruthenberg, H., 1980. Farming Systems in the Tropics. Clarendon Press, Oxford (3rd edition), 424p.

699

Scoones, I., 1994. Living with uncertainty: new directions in pastoral development in Africa. London : Intermediate Technology Publications, 210p.

702

Seligman, N. G., Perevolotsky, A., 1994. Has intensive grazing by domestic livestock degraded

Mediterranean Basin rangelands?. In Arianoutsou, M., Groves, R. H., (Eds), Plant animal interactions in

Animal Production and Health Paper, 127. 
Sraïri, M.T., 2005. Agronomic engineering and family farming in developing countries today. Reflections from Morocco [In French]. Cahiers Agricultures. 14, 485-491.

Sraïri, M.T., Kuper, M., Le Gal, P.Y., 2011. Supporting dairy farms by improving water productivity in the Tadla irrigation scheme (Morocco) [In French]. Cahiers Agricultures. 20, 60-66.

Sraïri, M.T., Chergui, S., Igueld, H.,Sannito, Y., 2014. Performances of family dairy farms in Morocco: arguments for improving farm milk price and technical support. Revue d'Elevage et de Médecine http://remvt.cirad.fr/cd/derniers_num/2014/REMVT14_183_191.pdf

720

721

Sraïri, M.T., Benjelloun, R., Karrou, M., Ates, S., Kuper, M., 2016. Biophysical and economic water productivity of dual purpose cattle farming. Animal. 10, 283-291.

Srairi, M.T., Ghabiyel, Y. 2017. Coping with the work constraints in crop-livestock farming systems. Annals of Agricultural Science. 62, 23-32.

Swinton, S., 1988. Drought survival tactics of subsistence farmers in Niger. Human Ecology. 16 (2), 123144.

Thomas, L., 2014. Diagnostic agraire d'une petite région agricole des garrigues. Mémoire de fin d'etude d'ingénieur d'AgroParisTech, INRA, $42 \mathrm{p}$. https://climed.cirad.fr/content/download/4556/32952/version/3/file/WP2_Thomas+Louisanne_Synth\%C3 \%A8se+Diag+Agraire+Garrigues+-+sept+2014.pdf (accessed 18 June 2018). 
735 Turner, M.D., 2000. Drought, Domestic Budgeting and wealth distribution in sahelian households. 736 Development and change. 31, 1009-1035.

737

738 Turner, M.D., Williams, T.O., 2002. Livestock market dynamics and local vulnerabilities in the Sahel.

739 World development. 30(4), 683-705.

740

741 Turner II, B.L., 2010. Vulnerability and resilience: Coalescing or paralleling approaches for sustainability 742 science? Global Environmental Change. 20, 570-576.

743

744 World Business Council for Sustainable Development (WBCSD),

745 http://www.wbcsd.org/templates/TemplateWBCSD5/layout.asp?MenuID=1

746

747 


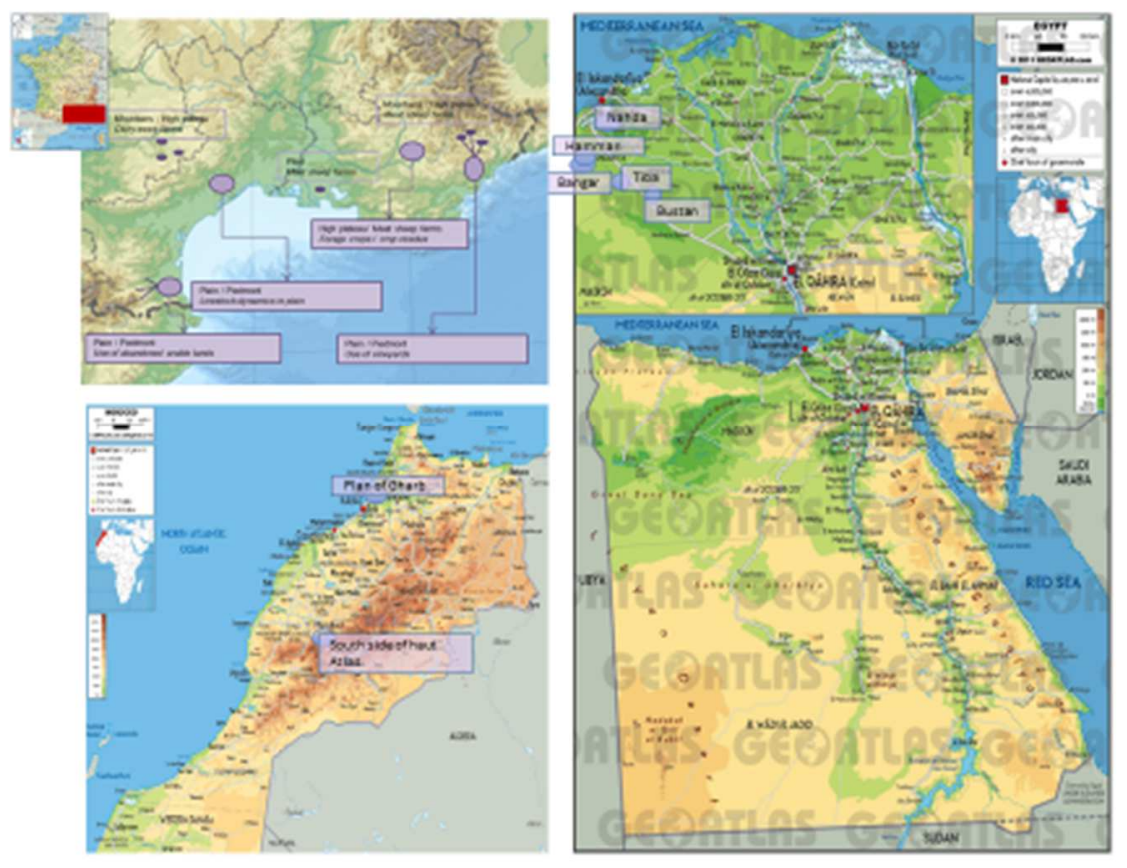

Figure 1. Geographical location of the selected case studies in the three countries. (a) (up left) in South of France; (b) (at right) the five locations in the Western Desert of the Nile Delta (Source: @ geoatlas.com); (c) (down left) from the Plain of Gharb to the South side of the haut Atlas (Source: @ geoatlas.com) 


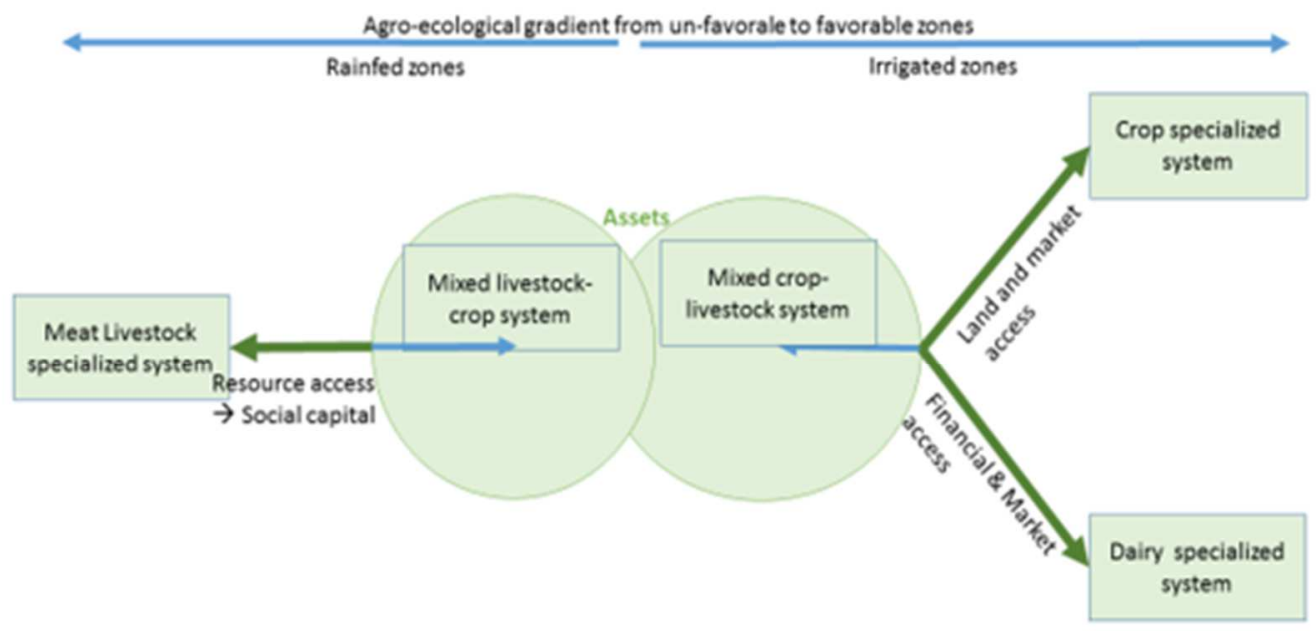

Figure 2. A descriptive approach of five Farming Systems in opposite trends towards specialization or diversification, in contrasted socio-ecological contexts en Mediterranean, from case studies in Egypt, France and Morocco 
Table 1. Materials collected in the three Mediterranean countries

\begin{tabular}{|c|c|c|c|}
\hline Country & Approach & Sample & Main variables \\
\hline \multirow[t]{2}{*}{ Egypt } & $\begin{array}{l}\text { Farm survey with semi structure } \\
\text { questionnaire (175 family farms } \\
\text { with less than } 10 \text { ha of arable } \\
\text { land) }\end{array}$ & 175 farms & $\begin{array}{l}\text { Narrative approach ('Récit de vie'), } \\
\text { Socio-economic living conditions, } \\
\text { Land tenure and crop land allocation, } \\
\text { Livestock and animal products' } \\
\text { management }\end{array}$ \\
\hline & $\begin{array}{l}\text { Bi-Monthly Crop-livestock } \\
\text { monitoring with questionnaire } \\
\text { (based on the Laser toolkit, } \\
\text { http://livtools.cirad.fr/) }\end{array}$ & 20 farms & $\begin{array}{l}\text { Crop management, feeding systems, } \\
\text { livestock products (milk \& meat, live } \\
\text { animals) }\end{array}$ \\
\hline \multirow[t]{3}{*}{ Morocco } & Annual follow up & 5 farms & $\begin{array}{l}\text { Understanding the relationship } \\
\text { between the feeding characteristics of } \\
\text { the herd and milk yield and the } \\
\text { setbacks recorded in milk production }\end{array}$ \\
\hline & Farm survey on livestock system & 19 farms & $\begin{array}{l}\text { Milk production costs (input/output) } \\
\text { (late winter } 2013 / 14 \text {; late spring } 2014 \text { ) }\end{array}$ \\
\hline & Follow up of work management & 14 farms & $\begin{array}{l}\text { Using the 'Work Balance' method to } \\
\text { assess tasks duration, the split of work } \\
\text { between family members and hired off } \\
\text { farm workers, and measuring the } \\
\text { generated income }\end{array}$ \\
\hline France & $\begin{array}{l}\text { Agrarian diagnosis, } \\
\text { comprehensive analysis of crop } \\
\text { livestock integration schemes }\end{array}$ & $\begin{array}{l}\text { Opened } \\
\text { interviews } \\
\text { with actors } \\
\text { and farmers }\end{array}$ & $\begin{array}{l}\text { Mobility, use of rangeland and } \\
\text { grassland, land management, typology } \\
\text { 'à dire d'acteur', perception (Aesthetic } \\
\text { value of landscape, cultural identity) }\end{array}$ \\
\hline
\end{tabular}


Table 2: Eight major drivers of farming systems' strengths or weaknesses in terms of sustainability

\begin{tabular}{|c|c|c|c|}
\hline Drivers & Some sources & Hypothesis & Variables used \\
\hline $\begin{array}{l}\text { Agro-ecological } \\
\text { context (relief, } \\
\text { soil) }\end{array}$ & $\begin{array}{l}\text { Mac Allister et al. 2006; } \\
\text { Ploeg, 1994; Cecchi et al., } \\
\text { 2010; Seligman and } \\
\text { Perevolotsky, 1994; } \\
\text { Berkes, 2007 ; Lavorel, } \\
\text { 1999; Blondel, } 2006 .\end{array}$ & $\begin{array}{l}\text { The diversity reinforces the } \\
\text { adaptive capacity to natural and } \\
\text { social chocks. }\end{array}$ & $\begin{array}{l}\text { Soil quality; landscapes } \\
\text { diversity, level of biodiversity } \\
\text { based on agrarian system } \\
\text { approach; }\end{array}$ \\
\hline Drought risk & $\begin{array}{l}\text { Séré and Steinfeld (1996); } \\
\text { Turner, 2000; Swinton, } \\
\text { 1988; Berkes, 2007; } \\
\text { Brooks } 2006\end{array}$ & $\begin{array}{l}\text { Many long-enduring societies } \\
\text { have developed adaptations to } \\
\text { deal with drought incidence. }\end{array}$ & $\begin{array}{l}\text { Variability of annual rainfall; } \\
\% \text { of dry matter from pastures; } \\
\text { herd mobility; annual forages } \\
\text { and purchased feeds based on } \\
\text { farm survey and monitoring }\end{array}$ \\
\hline Water access & Ellis and Mdoe, 2003 & $\begin{array}{l}\text { Water supply (accessibility and } \\
\text { quality) conditions the } \\
\text { agricultural activities and defines } \\
\text { ways crop and livestock interact } \\
\text { within farming activities }\end{array}$ & $\begin{array}{l}\text { Water supply for agriculture } \\
\text { based on farm survey; }\end{array}$ \\
\hline $\begin{array}{l}\text { Market access } \\
\text { (opportunity) }\end{array}$ & $\begin{array}{l}\text { Ridaura, 2005; Cecchi et } \\
\text { al, } 2010 \text {; Ellis and Mdoe, } \\
\text { 2003; Eakin, 2005; Turner } \\
\text { et Williams, 2002; }\end{array}$ & $\begin{array}{l}\text { The adaptive capacity depends on } \\
\text { the role and functioning of rural } \\
\text { markets (access and distance to } \\
\text { market, price negotiation system, } \\
\text { debt negotiation) }\end{array}$ & $\begin{array}{l}\text { Localization and } \\
\text { infrastructure of markets } \\
\text { based on agrarian system } \\
\text { approach and interviews }\end{array}$ \\
\hline Land/resources & $\begin{array}{l}\text { Fraser and Stringer. 2009; } \\
\text { Ellis, 2000; Ellis and } \\
\text { Mdoe, } 2003\end{array}$ & $\begin{array}{l}\text { Redefine crop livestock } \\
\text { integration is a way to comfort } \\
\text { access to forage as land access } \\
\text { and land tenure are critical for } \\
\text { livestock farmers }\end{array}$ & $\begin{array}{l}\text { Land access; location/quality } \\
\text { of land, land tenure based on } \\
\text { farm survey and narrative } \\
\text { approach }\end{array}$ \\
\hline Policy support & $\begin{array}{l}\text { Agder and Vincent, 2005; } \\
\text { Turner and Williams, } \\
\text { 2002; Scoones, 1994; }\end{array}$ & $\begin{array}{l}\text { Institutional stability; The public } \\
\text { policies affected the de-stocking } \\
\text { during drought events, causing the } \\
\text { depletion of natural resources due } \\
\text { to overgrazing }\end{array}$ & $\begin{array}{l}\text { Feed or grain subsidies; credit } \\
\text { access; agro-environmental } \\
\text { measurement based on } \\
\text { literature review }\end{array}$ \\
\hline $\begin{array}{l}\text { Collective } \\
\text { action/social } \\
\text { coordination }\end{array}$ & $\begin{array}{l}\text { Berkes et al., 2003; Folke } \\
\text { et al, 2005; Turner } \\
\text { II, 2010, Ellis and Mdoe, } \\
\text { 2003; Berkes, 2007; } \\
\text { Olsson et al., } 2004 \text {; Ploeg, } \\
2004\end{array}$ & $\begin{array}{l}\text { The social dimension of adaptive } \\
\text { co-management of ecosystems } \\
\text { and landscapes, referred to as } \\
\text { "systems of adaptive } \\
\text { governance", are strongly based } \\
\text { on "bridging organizations", and } \\
\text { then their social capacities to deal } \\
\text { with permanent uncertainties, } \\
\text { perturbations. }\end{array}$ & $\begin{array}{l}\text { Social network; ways of } \\
\text { communication and } \\
\text { infrastructure (road, } \\
\text { electricity,..); extension and } \\
\text { social service (proximity, } \\
\text { number of visits); formal and } \\
\text { informal institutions based on } \\
\text { farm survey and interview }\end{array}$ \\
\hline Solidarity & $\begin{array}{l}\text { Ellis and Mdoe, } \\
\text { 2003; Alary et al, 2016b; } \\
\text { Eakin, 2005; Chambers, } \\
\text { 2006; Dougill et al } 2010\end{array}$ & $\begin{array}{l}\text { The solidarity is a factor } \\
\text { reinforcing family net safety }\end{array}$ & $\begin{array}{l}\text { Distance between actors, } \\
\text { frequency of contacts; } \\
\text { network, membership of } \\
\text { groups, relationships of trust, } \\
\text { access to wider institutions of } \\
\text { society; ability to move } \\
\text { animals; }\end{array}$ \\
\hline
\end{tabular}


Table 3: Type of work and family work productivity in three farm types in the plain of Gharb, Morocco (14 farms in 2014)

\begin{tabular}{|l|c|c|c|}
\hline FS & Livestock system & Horticultural system & $\begin{array}{c}\text { Mixed Crop- } \\
\text { Livestock system }\end{array}$ \\
\hline Sample size & 6 & 3 & 5 \\
\hline Arable land (ha) & 9 & 28.3 & 43.7 \\
\hline Main cash crops & Maize, sugar beet & $\begin{array}{c}\text { Potato, watermelon, } \\
\text { sugar beet, sunflower, rice }\end{array}$ & $\begin{array}{c}\text { Cereal, peanut, bean, } \\
\text { rice }\end{array}$ \\
\hline Livestock Units (LU) & 11.4 & 8.9 & 16.9 \\
\hline Fodder area/Total land (\%) & 47 & 12 & 10 \\
\hline Family members involved in work & 3.2 & 3.7 & 3 \\
\hline Routine work (days) & 673.2 & 491.5 & 524.7 \\
\hline Seasonal work on crops (days) & 136.1 & 930.4 & 271.9 \\
\hline Work autonomy (\%) & 75 & 62 & 45 \\
\hline Income generated per LU (€) & 997 & 536 & 1058 \\
\hline Income per ha of crops (€) & 554 & 1052 & 8391 \\
\hline Total livestock income (€/year) & 11362 & 4769 & 41598 \\
\hline Total crop income (€/year) & 2646 & 26258 & 17 \\
\hline Livestock income/total income (\%) & 81 & 15 & 1389 \\
\hline Labor productivity (€/month/family worker) & 365 & 699 & \\
\hline
\end{tabular}

\footnotetext{
* 1 LU equivalent 1 UGB
} 
Table 4. Parameters of economic and environmental efficiency for the six farm types in the New Reclaimed Lands of West Delta (Egypt) according to a gradient of specialization and diversification (175 farms)

\begin{tabular}{lcccccc}
\hline Farming system & $(\mathrm{G} 1)$ & $(\mathrm{G} 2)$ & $(\mathrm{G} 3)$ & $(\mathrm{G} 4)$ & (G5) & (G6) \\
\hline No of dairy heads (heads) & $2-3$ & $3-6$ & $5-6$ & $17-18$ & -- & $2-3$ \\
\hline Area (feddan) & 2.5 & 2.5 & 6.7 & 14.7 & 6.8 & 6.4 \\
\hline Tree area (\%/total area) & 7 & 13 & 10 & 22 & 64 & 51 \\
\hline Dairy specialization (\%/total animal products) & 33 & 27 & 35 & 40 & 2 & 29 \\
\hline Organic matter (\%/total N supply) & 40 & 42 & 30 & 40 & 48 & 33 \\
\hline Feed efficiency (feed cost in $€ /$ liter) & 0.43 & 0.57 & 0.46 & 0.34 & -- & 0.61 \\
\hline Total net income/workforce (€/year/full time unit) & 100 & 476 & 397 & 903 & 788 & 603 \\
\hline Total net income/land unit (€/feddan/year) & 110 & 258 & 195 & 374 & 103 & 151 \\
\hline Total net income/capita/year (€) & 37 & 97 & 126 & 343 & 183 & 171 \\
\hline
\end{tabular}

Legend : (G1) Small C\&L system; (G2) Small C\&L system oriented to crops; (G3) medium C\&L systems; (G4) Large C\&L oriented to livestock; (G5) Tree-specialized systems; (G6) C\&L systems oriented to trees 
Table 5. Adaptive capacities of livestock systems based on three coordination models to access feed resources from cultivated land (South of France)

\begin{tabular}{llll}
\hline Models & Vicinity grazing & Distant grazing & $\begin{array}{l}\text { Distant forage cropping } \\
\text { Plain /Mountain }\end{array}$ \\
\hline Types of relations & Neighbor & Inter-individual & Multi-actors \\
\hline Mode of coordination & Proximity & Mutual agreement & Collective action \\
\hline Temporal coordination & ++ & +++ & +++ \\
\hline Spatial coordination & + & ++ & +++ \\
\hline Social coordination & +++ & +++ & +++ \\
\hline
\end{tabular}


Table 6. Importance of the five farming systems in three Mediterranean countries, based on expert knowledge

\begin{tabular}{|c|c|c|c|c|c|}
\hline & $\begin{array}{c}\text { Crop- } \\
\text { Specialized } \\
\text { system }\end{array}$ & $\begin{array}{c}\text { Dairy } \\
\text { specialized } \\
\text { systems }\end{array}$ & $\begin{array}{c}\text { Mixed crop- } \\
\text { livestock system }\end{array}$ & $\begin{array}{c}\text { Mixed } \\
\text { livestock- } \\
\text { crop system }\end{array}$ & $\begin{array}{c}\text { Meat } \\
\text { specialized } \\
\text { systems }\end{array}$ \\
\hline $\begin{array}{l}\text { Agro-ecological } \\
\text { conditions }\end{array}$ & Very favorable & Favorable & Intermediary & Rain-fed & Rain-fed \\
\hline \multicolumn{6}{|c|}{ Importance of farming systems in each Mediterranean countries (in number of farms) } \\
\hline South of France & +++ & 0 & 0 & + & +++ \\
\hline Morocco & ++ & + & +++ & +++ & ++ \\
\hline Egypt & $++($ fruit trees $)$ & + & +++ & +++ & + \\
\hline
\end{tabular}

Legend: the weight $(+++/++/+/ 0)$ estimated according to opened interviews among key-resource persons in each case study; 0 meaning the quasi-absence of the system. 
Table 7. Eco-efficiency evaluation of five farming systems in three Mediterranean countries

\begin{tabular}{|l|l|l|l|l|l|}
\hline & $\begin{array}{l}\text { Crop- } \\
\text { Specialized } \\
\text { system }\end{array}$ & $\begin{array}{l}\text { Dairy } \\
\text { specialized } \\
\text { systems }\end{array}$ & $\begin{array}{l}\text { Mixed crop- } \\
\text { livestock system }\end{array}$ & $\begin{array}{l}\text { Mixed } \\
\text { livestock- } \\
\text { crop system }\end{array}$ & $\begin{array}{l}\text { Meat specialized } \\
\text { systems }\end{array}$ \\
\hline Gradient & Very favorable & Favorable & Intermediary & Rain-fed & Rain-fed \\
\hline $\begin{array}{l}\text { Nitrogen use } \\
\text { efficiency }\end{array}$ & - & + & + & + & + \\
\hline $\begin{array}{l}\text { Economic } \\
\text { vulnerability }\end{array}$ & - & - & + & $+/-$ & - \\
\hline \begin{tabular}{l} 
Labor productivity \\
\hline
\end{tabular} & + & + & - & - & $+/-$ \\
\hline
\end{tabular}

Legend: (+) meaning positive value indicators for the farming system in all case studies; (-) meaning negative or low value indicators for the farming system in all case studies; $(+/-)$ meaning the two trends (positive and negative/low values) for the farming system according to the case study. 
Table 8. Strengths and weaknesses of five farming systems at the farm and territorial level in three Mediterranean countries, according to eight major drivers

\begin{tabular}{|c|c|c|c|c|c|}
\hline & $\begin{array}{l}\text { Crop- } \\
\text { Specialized } \\
\text { system }\end{array}$ & $\begin{array}{l}\text { Dairy } \\
\text { specialized } \\
\text { systems }\end{array}$ & $\begin{array}{l}\text { Mixed crop- } \\
\text { livestock } \\
\text { system }\end{array}$ & $\begin{array}{l}\text { Mixed } \\
\text { livestock- } \\
\text { crop }\end{array}$ & $\begin{array}{l}\text { Meat } \\
\text { specialized } \\
\text { systems }\end{array}$ \\
\hline $\begin{array}{l}\text { Agro-ecological context } \\
\text { (relief, soil) }\end{array}$ & +++ & +++ & ++ & -- & --- \\
\hline Drought risk & +++ & +++ & + & --- & - \\
\hline Water access & +++ & +++ & - & --- & - \\
\hline Market access (opportunity) & ++ & +++ & --- & --- & ++ \\
\hline Land/resources & +++ & +++ & --- & -- & ++ \\
\hline Policy support & +++ & +++ & --- & -- & ++ \\
\hline $\begin{array}{l}\text { Collective action/social } \\
\text { coordination }\end{array}$ & ++ & -- & --- & - & +++ \\
\hline Solidarity $\rightarrow$ net safety & - & + & ++ & ++ & ++ \\
\hline
\end{tabular}

